\title{
PRODUCTION OF HIGH FRUCTOSE SYRUP FROM JERUSALEM ARTICHOKE TUBERS USING KLUYVEROM YCES MARXIANUS CELLS IMMOBILIZED IN AGAR GEL
}

\author{
PRATIMA BAJPAI ${ }^{1}$ AND ARGYRIOS MARGARITIS \\ Chemical and Biochemical Engineering, Faculty of Engineering \\ Science, The University of Western Ontario, \\ London, Ontario, Canada N6A 5 B9
}

(Received March 22, 1985)

\begin{abstract}
Hydrolysis of inulin from Jerusalem artichoke tuber extract by cells of the yeast Kluyveromyces marxianus immobilized in agar has been studied in batch and packed bed bioreactor systems. In a batch reactor using around 43 units of enzyme activity, about $94 \%$ hydrolysis of the total potential sugars was achieved in $10 \mathrm{hr}$. The product consisted of about $90 \%$ fructose and $10 \%$ glucose. The same immobilized cells were used repeatedly for 9 cycles starting with fresh juice at the beginning of each cycle. The activity of the immobilized cells remained more or less constant during the first 5 cycles but beyond that it started to decrease. The maximum conversion rate obtained after 9 batch cycles was about $48 \%$ of the original. In column reactors, packed with 103 units of enzyme activity, the conversion rate remained almost constant at dilution rates lower than $0.34 \mathrm{hr}^{-1}$ but decreased beyond $0.34 \mathrm{hr}^{-1}$. The productivity at dilution rates $D=1.1 \mathrm{hr}^{-1}$ and $0.61 \mathrm{hr}^{-1}$ was calculated to be $46 \mathrm{~g} \cdot l^{-1}$. $\mathrm{hr}^{-1}$ and $31 \mathrm{~g} \cdot \mathrm{l}^{-1} \cdot \mathrm{hr}^{-1}$ respectively and the corresponding conversion rates were 76 and $95 \%$. Continuous operation of the column at a constant dilution rate of $D=0.61 \mathrm{hr}^{-1}$ for 15 days at $45^{\circ} \mathrm{C}$, resulted in $43 \%$ loss of the original activity. The half life of the bioreactor was estimated to be 17 days.
\end{abstract}

In a previous paper ( 1 ) the preliminary results of immobilization of Kluyveromyces marxianus cells having inulinase in agar gel were reported. In this paper, the application of immobilized cells for the production of high fructose syrup in batch, repeated batch and continuous process is presented. The long term stability of the immobilized cells is also reported.

1 To whom all correspondence should be addressed at: Division of Chemical and Biochemical and Engineering, Thapar Corporate Research and Development Centre Patiala 147001 , India. 


\section{MATERIALS AND METHODS}

Extraction of juice from Jerusalem artichoke tubers. Tubers were first cut into small pieces and then ground to a coarse pulp using a food grinder. The juice was then taken out of the pulp with a normal screw press. The remaining pulp was extracted twice with distilled water at room temperature. The extracts were then added to the expressed juice $(2,3)$. The concentration of total carbohydrates in the artichoke juice used for batch and continuous hydrolysis was around $56.3 \mathrm{~g} / \mathrm{l}$ and the concentration of initial total reducing sugars was $3.8 \mathrm{~g} / \mathrm{l}$. All the results presented here are those obtained after subtracting the inital total reducing sugars.

Immobilization method. Dead cells of Kluyveromyces marxianus UCD (FST) 55-82 were immobilized by the method reported earlier (I).

Assay of enzyme activity and sugars. The activity of the immobilized cells was determined by the method reported earlier (I). Total reducing sugars were determined by the dinitrosalicylic acid method (4) and total sugars were determined by the anthrone method (5). D-Glucose was assayed using the glucose oxidase method (6) and D-fructose was determined as the difference between the amount of total reducing sugars and glucose (7-9).

Batch hydrolysis. Batch hydrolysis was carried out in $500-\mathrm{ml}$ stoppered flasks in a rotary shaker at $35^{\circ} \mathrm{C}$ and $150 \mathrm{rpm}$. Immobilized cells containing about 43 units of enzyme activity were added to $100 \mathrm{ml}$ of artichoke tuber extract. Samples were taken at regular intervals and the reaction was stopped by heating the reaction mixture in a boiling water bath. For the purpose of comparison, hydrolysis with $50 \mathrm{~g} / /$ standard inulin was also carried out under similar conditions. Batch hydrolysis of artichoke tuber extract with immobilized cells was repeated 9 times.

Continuous hydrolysis. Continuous hydrolysis of artichoke tuber extract was carried in a packed bed bioreactor. The bioreactor consisted of a borosilicate glass column $(2 \mathrm{~cm}$ i.d. and $28 \mathrm{~cm}$ length) surrounded by a water jacket. The column was loaded with immobilized cells that contained around 103 units of enzyme activity. The void volume (total bioreactor volume minus volume of immobilized cells) was $42 \%$ of the total working bioreactor volume of $85 \mathrm{ml}$. The extract of artichoke tubers was passed through the column at $45^{\circ} \mathrm{C}$. The dilution rate for the packed bed bioreactor was determined from the reciprocal of the liquid phase mean residence time as described by KrouwEL and KOSSEN (10). The productivity and conversion were examined by varying the flow rate after the steady state had been reached at each flow rate. The effluent concentrations of glucose and total reducing sugars were determined at steady state conditions.

Long term stability of the immobilized cells. The long term stability of the immobilized cells was determined in the packed bed bioreactor. Stability was investigated at a dilution rate of $D=0.61 \mathrm{hr}^{-1}$ for the hydrolysis of artichoke tuber 
extract at $45^{\circ} \mathrm{C}$ and $\mathrm{pH} 5.5$ for $360 \mathrm{hr}$.

\section{RESULTS AND DISCUSSION}

Kinetics of hydrolysis of inulin and artichoke tuber extract with immobilized cells in a batch reactor

Figures 1 and 2 show the hydrolysis of pure inulin and artichoke tuber ex-

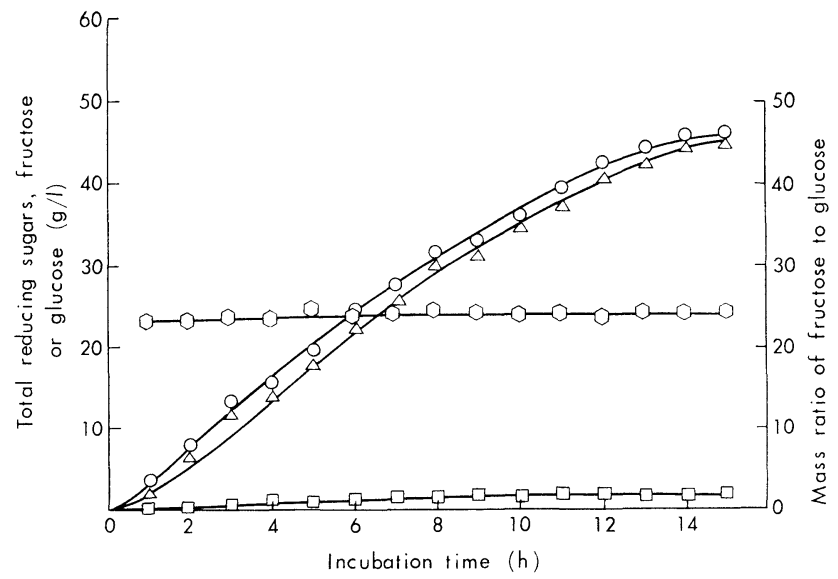

Fig. 1. Batch hydrolysis of pure inulin with agar-immobilized $K$. marxianus cells.

$\bigcirc$ : total reducing sugars, $\triangle$ : fructose, $\square$ : glucose, $\bigcirc$ : mass ratio of fructose to glucose.

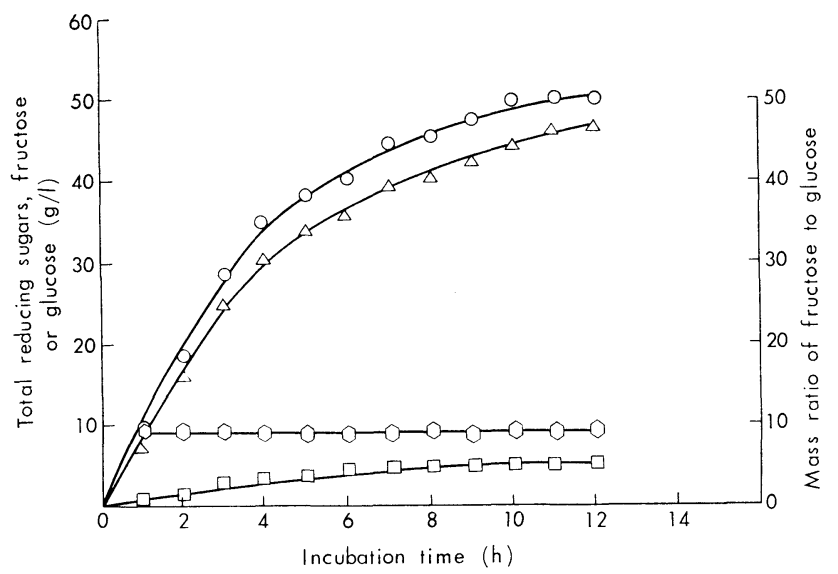

Fig. 2. Batch hydrolysis of artichoke tuber extract with agar-immobilized $K$. marxianus cells.

$\bigcirc$ : total reducing sugars, $\triangle:$ fructose, $\square$ : glucose, $\bigcirc$ : mass ratio of fructose to glucose. 
tract by the immobilized cells. Percent hydrolysis was found to be $94 \%$ with the artichoke tuber extract and $92 \%$ with the standard inulin. The rate of hydrolysis of fructose-containing polymers in the tuber extract was much greater than that standard inulin. About 35, 72 and $94 \%$ of total sugars of the tuber extract were hydrolyzed in 2, 5 and $10 \mathrm{hr}$ respectively while only 15,38 and $72 \%$ of the inulin was hydrolyzed during these same periods. The results can be explained by the kinetic properties of inulinase towards the substrate in the tuber extracts. It seems that polymers having a low degree of polymerization, including sucrose, were hydrolyzed more rapidly than those with higher degrees of polymerization. BYUN and Nahm (7) and Guiraud and Galzy ( $1 /$ ) obtained similar results with Kluyveromyces fragilis and Debaryomyces phaffi inulinases. During the enzymatic hydrolysis of standard inulin, the ratio of the amount of fructose to glucose produced was maintained at about 24 . This value is a little lower than 35 which is the number of fructose residues in inulin. The difference in the ratio might be caused by the difference in the degree of polymerization of standard inulin as it varies according to the source of polymers and storage treatment $(12,13)$. The product from the tuber extract contained about $90 \%$ fructose and $10 \%$ glucose as a mixture. Bell and PALMER (14) have reported that certain preparations of inulin have a glucose content of $2 \%$, which would correspond to an average chain length of 50 residues/glucose. BACON and LOXLEY (13) found that inulin consisted of $98 \%$ fructose and $2 \%$ glucose when the tubers were harvested. During cold storage however, enzymes in the tubers depolymerize the inulin to form low molecular weight oligomeric fructose polymers so the percentage of glucose in the polymers increases. EDELMAN and JEFFORD (12) and BACON and LOXLEY (13) observed that the glucose content in the tubers increased to $25 \%$ during storage. Since our artichoke tubers were stored at $-4^{\circ} \mathrm{C}$ for 2 months after harvest, some depolymerization of inulin in the tubers probably took place and therefore the glucose content in the tubers increased to $10 \%$.

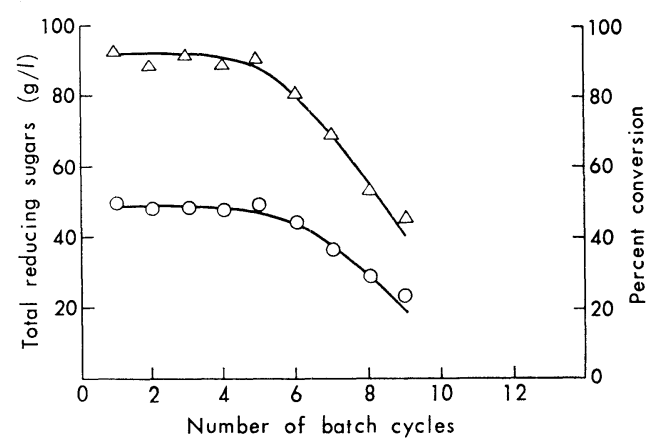

Fig. 3. Repeated use of agar-immobilized $K$. marxianus cells for the batch production of fructose.

$\triangle:$ percent conversion, $\bigcirc$ : total reducing sugars. 


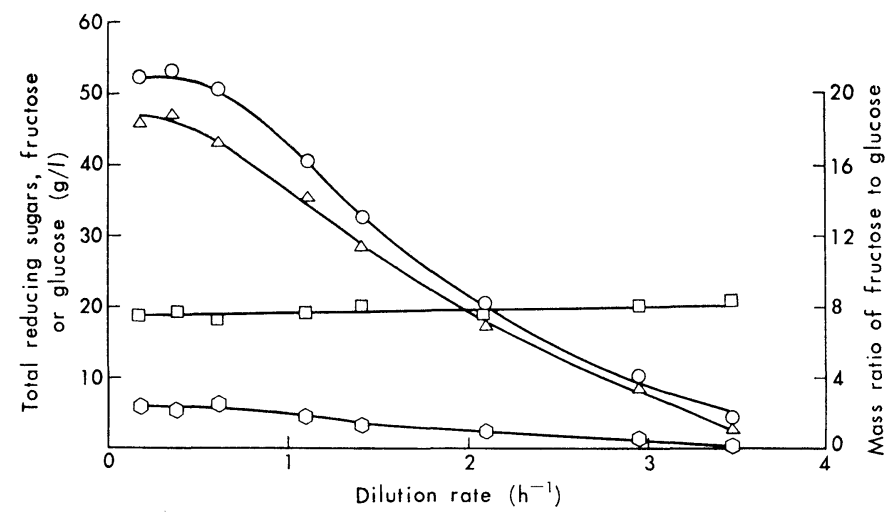

Fig. 4. Total reducing sugars, fructose or glucose concentration and mass ratio of fructose to glucose as a function of dilution rate for immobilized cells of $K$. marxianus.

$O$ : total reducing sugars, $\triangle$ : fructose, $O$ : glucose, $\square$ : mass ratio of fructose to glucose.

In Fig. 3, repeated batch hydrolysis of artichoke tuber extract using the immobilized cells for total of 9 batches is presented. After about every $9 \mathrm{hr}$, the liquid broth was removed and fresh sterilized artichoke tuber extract was added to the Erlenmayer flask containing the immobilized cells. As can be seen from the data, the percentage of hydrolysis was more or less constant during the first 5 batch cycles but it started to decrease after that. The maximum conversion obtained after 9 batch cycles was about $48 \%$ of the original obtained during the first batch cycle.

Kinetics of hydrolysis of artichoke tuber extract in packed bed bioreactor

Figures 4 and 5 show the results of continuous hydrolysis of artichoke tuber extract with the immobilized cells in a packed bed bioreactor. In Fig. 4, concentrations of fructose, glucose, and total reducing sugars are plotted as a function of dilution rate. The concentration of total reducting sugars was constant at low dilution rates i.e. form $D=0.16$ to $0.34 \mathrm{hr}^{-1}$ but it decreased at dilution rates higher than $D=0.34 \mathrm{hr}^{-1}$. The maximum total reducing sugars concentration was 52.9 $\mathrm{g} / \mathrm{l}$ at $D=0.16$ to $0.34 \mathrm{hr}^{-1}$. The mass ratio of fructose to glucose was about 8 and it did not change with the increase in dilution rates. From the data presented in Fig. 4, percent hydrolysis and total reducing sugars productivity have been calculated and are shown in Fig. 5. As the dilution rate increased, volumetric total reducing sugars productivity also increased but beyond a dilution rate of $D=1.4$ $\mathrm{hr}^{-1}$ it began to decline. Thus, the optimum dilution rate for maximum volumetric total reducing sugars productivity $\left(46 \mathrm{~g} \cdot l^{-1} \cdot \mathrm{hr}^{-1}\right)$ is found to be around 1.4 $\mathrm{hr}^{-1}$. The conversion ratio was $62 \%$ at $D=1.4 \mathrm{hr}^{-1}$. At a dilution rate of $D=$ $1.1 \mathrm{hr}^{-1}$ and $0.61 \mathrm{hr}^{-1}$, the productivities were found to be $45 \mathrm{~g} \cdot l^{-1} \cdot \mathrm{hr}^{-1}$ and $31 \mathrm{~g}$. 


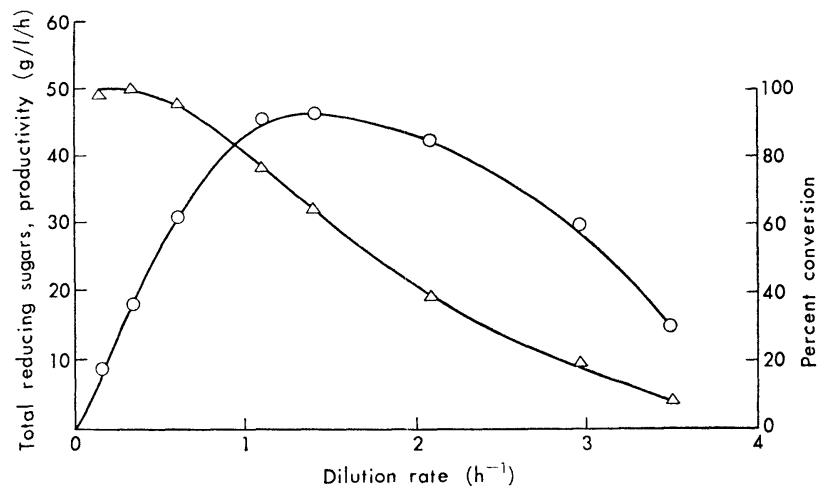

Fig. 5. Total reducing sugars productivity and percent conversion as a function of dilution rate by immobilized cells of $K$. marxianus.

$\bigcirc$ : total reducing sugars productivity, $\Delta$ : percent conversion.

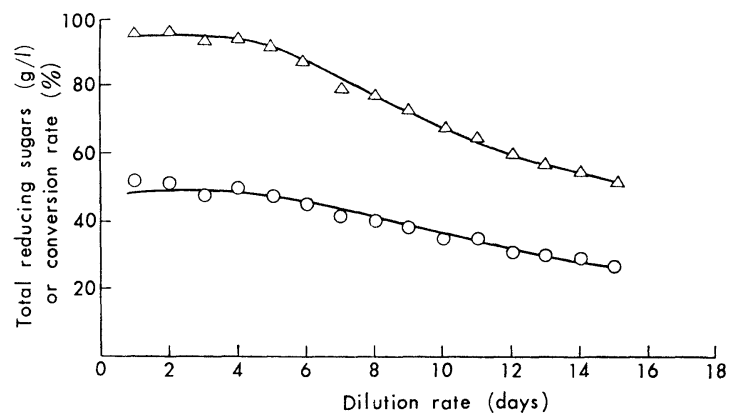

Fig. 6. Conversion rate and total reducing sugars concentration as a function of dilution rate for immobilized cells of $K$. marxianus.

$\triangle$ : conversion rate, $\bigcirc$ : total reducing sugars.

$l^{-1} \cdot \mathrm{hr}^{-1}$ respectively and the corresponding conversion rates, were 76 and $95 \%$. KIM and BYUN (8) have reported a maximum productivity of $18 \mathrm{~g} \cdot l^{-1} \cdot \mathrm{hr}^{-1}$ (calculated on total volume basis) at $90 \%$ conversion using Kluyveromyces fragilis inulinase immobilized by amino ethyl cellulose with $50 \mathrm{~g} / /$ total carbohydrate concentration as feed. GUIRAUD et al. (15) reported maximum productivity of $22 \mathrm{~g}$. $l^{-1} \cdot \mathrm{hr}^{-1}$ (based on total volume) at $100 \%$ conversion utilizing Debaryomyces phaff inulinase for an inlet carbohydrate concentration of $5 \mathrm{~g} / l$. Thus, our productivities compare well with the results published elsewhere.

Long term stability of the immobilized cells

The long term stability of the immobilized cells was also determined in the packed bed bioreactor. Artichoke tuber extract containing total sugars $(50 \mathrm{~g} / l)$ 
was passed continuously at a dilution rate of $D=0.61 \mathrm{hr}^{-1}$ at $45^{\circ} \mathrm{C}$ for 15 days. Operational stability of the immobilized cells is presented in Fig. 6. No significant change in steady state conversion was observed during the first 5 days but beyond the fifth day, the activity started to decrease. During the 15 days operation of the column, the conversion rate was found to decline from 95 to $52 \%$. These data show about $43 \%$ loss of the original activity after 15 days of continuous operation at a dilution rate of $0.61 \mathrm{hr}^{-1}$. On the basis of these data, the half life of the bioreactor operated at a dilution rate of $D-0.61 \mathrm{hr}^{-1}$ was estimated to be about 17 days. The half life of Kluyveromyces fragilis inulinase immobilized with amino ethyl cellulose in a packed bed column reactor was calculated to be 17.3 days for tuber extract containing $50 \mathrm{~g} / \mathrm{l}$ of total carbohydrates and 13.9 days for $7 \%$ inulin solution $(8)$.

This work was supported by strategic grant No. G04070 of the National Sciences and Engineering Research Council of Canada.

\section{REFERENCES}

l) P. Bajpai and A. Margaritis, J. Gien. Appl. Microbiol., 31, 297 (1985).

2) P. Bajpai and A. Margaritis, Annu. Meet. Can. Chem. Eng., Toronto, Canada, 1983.

3) P. BajPai and A. Margaritis, Eng. Microb. Technol., 7, 34 (1984).

4) J. B. Summer and G. F. Sommers, Laboratory Experiments in Biological Chemistry, Academic Press, New York (1944).

5) J. Weiner, J. Inst. Brew., 84, 222 (1978).

6) Worthingten Enzyme Manual, Worthingten Biochem. Corp., New York, 181 (1972).

7) S. M. Byun and B. H. NaHm. J. Food Sci., 43, 1871 (1978).

8) W. Y. Kim and S. M. Byun, Enzyme Microb. Technol., 4, 239 (1982).

9) W. Y. Kim, S. M. ByUn, and B. H. Nahm, Korean J. Food Sci. Tech., 11, 238 (1979).

10) P. G. Krouwel and N. W. F. Kossen, Biotechnol. Bioeng., 23, 651 (1981).

11) J. P. Guiraud and P. Galzy, Enzyme Microb. Technol., 3, 305 (1981).

12) J. Edelman and T. G. Jefford, New' Phytol., 67, 517 (1968).

13) J. S. D. BACON and R. LoXLEy, Biochem. J., 51, 208 (1952).

14) D. J. Bell and A. Palmer, J. Chem. Soc., 3763 (1952).

15) J. P. Guiraud, S. Demeuli.e, and P. Galzy, Biotechnol. Lett., 8, 683 (1981). 